\title{
THE SOCIAL ASPECT OF OPEN SPACE IN REHABILITATION GARDENS AND PARKS
}

\author{
Linda Balode \\ Latvia University of Agriculture \\ E-mail linda.balode2010@inbox.lv
}

\begin{abstract}
In the research process the landscape space of Latvian rehabilitation centers was inspected and analyzed within the social context. The centers were singled out not only by their aesthetical quality, but also by their functional landscape values contained. Rehabilitation gardens and parks are spaces, where people do more than receive medical treatment, they can relax surrounded by nature, engage in physical activities and rest without taking into account ones social status, age, gender, nationality, political views and religion. The goal is to summarize how Latvian rehabilitation gardens and parks promote patients' physical activities in open space and analyze the functional quality of landscape of Latvian rehabilitation gardens and parks. Considering the quality of rehabilitation center environment, it is important to evaluated their accessibility and usability by possibly greater user spectrum that is characterized as a universal design. In Latvia a conceptual direction of design like this is relatively new, but already positively accepted and applied by specialists. Open space designs of rehabilitation center landscaping directly influence how a person feels and lives in the landscape. They sculpt not only the material quality of the environment, but also improve people's communication facility and attitude towards one another. It is important for the environment of Latvian rehabilitation institutions to be friendly, because they are created for the use by all social groups and individuals by applying universal standard principles for open space improvement.
\end{abstract}

Keywords: rehabilitation garden and park, universal design, landscape usability, accessibility, social aspect.

\section{Introduction}

Studied and analyzed already in the Soviet times a positive influence of Latvian health resorts and rehabilitation centers on human recovery processes nowadays gets more and more re-evaluated and used for recovering (Polyanskiy 1988; Tkhor 1984) (Fig. 1). People, exhausted from pain and suffering, go to rehabilitation centers, which serve as the only hope for them in situations where there is no reason to count on medical help; the last thing that remains - to count on the experience, sensitivity, sympathy of people working in rehabilitation centers and on the healing power of nature. Silence, presence of the sea or any other water reservoir, mighty rustle of pines, sandy beach, mineral waters and unique mud heal human being physically and mentally.

The notion of social aspect in its essence includes the processes and activities that protect individual and collective rights of rehabilitation centers' patients, employees and visitors in such spheres as employment, consultations, health and safety by maintaining the balance between economics and social sphere. Rehabilitation gardens and parks are spaces where people do more than receive medical treat- ment, they can relax in nature, engage in physical activities and rest without taking into account one's social status, age, gender, nationality, political views and religion. Open space designs of the rehabilitation center landscaping influence directly how a person feels and lives in the landscape. It sculpt not only the material quality of the environment, but also improve people communication facility and attitude towards each other (Roger, Ulrich 2002). It is important for the environment of Latvian rehabilitation institutions to be friendly, because they are designed for the use by any social group and individual by appling the universal standard principles for open space upgrading.

The aim is to study and analyze functional quality of Latvian rehabilitation gardens and parks taking into consideration the social aspect - patients' opportunities for physical outdoor activities.

$\operatorname{Task}(s)$ :

- To study and analyze the landscape's functional quality of rehabilitation gardens and parks in Latvia;

- To carry out questionnaires and interviews in order to find out the opinions of the users of Latvian 


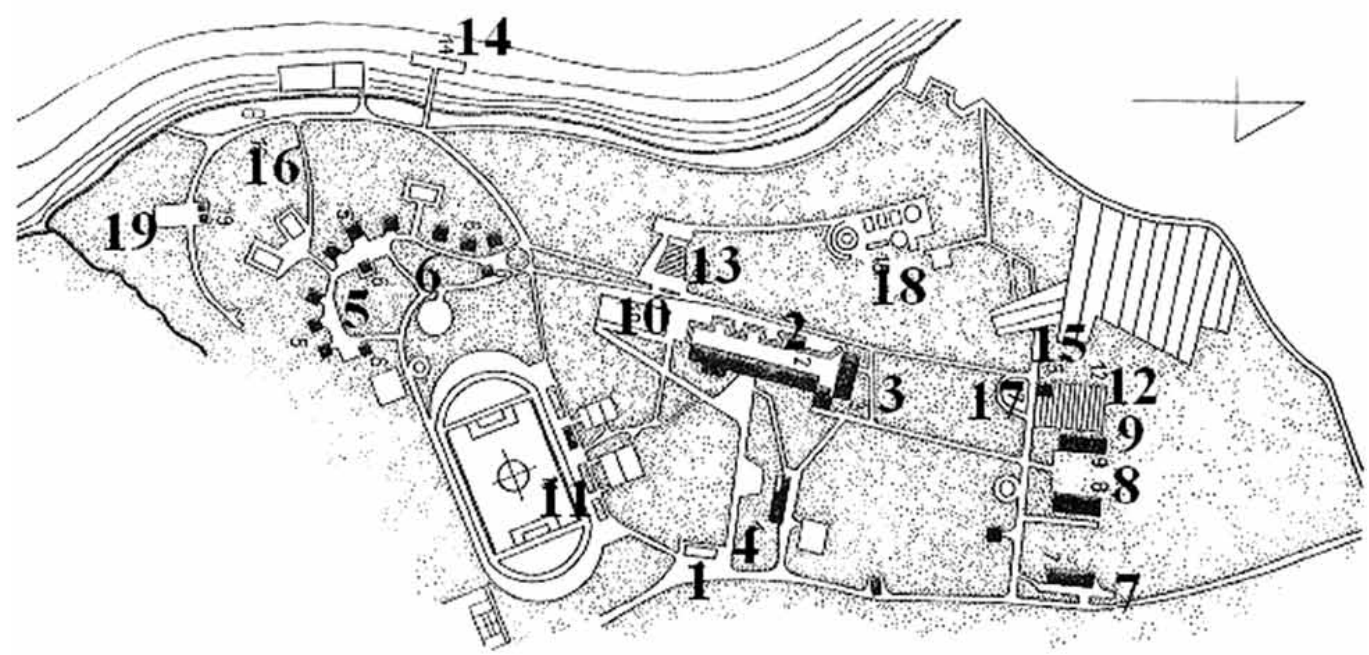

Fig. 1. Open space design of the Soviet times rehabilitation centre 'Zerkalny' landscaping, Russia. 1 - Entrance;

2 - Sleeping house; 3 - Dining; 4 - Administration; 5 - Summer camp; 6, 7, 15 - Personnel, Pioneers; 8 - Boiler house;

9 - Garden; 10 - Morning meeting place; 11 - Sports ground; 12 - Research garden; 13 - Summer theater;

14 - Boat station; 16 - Arbour; 17 - Animal garden; 18 - Carting track; 19 - WC.

Source: compiled by L. Balode (according to literature review based on (Tkhor 1984))

rehabilitation gardens and parks - patients, employees, visitors and experts on necessities and opportunities to rehabilitate outdoors.

Nowadays architecture, design and arts have to reflect directly the society's necessities, mental limits and technical possibilities, which have to be looked upon as a whole unit in the landscape space, based on human values and values of the time.

In order to ensure rehabilitation centers' high quality environment, it is important to observe its accessibility and usability for the user spectrum as extensive as possible, which is characterized as a universal design. In Latvia a conceptual direction of design like this is relatively new, but already positively accepted and applied among specialists.

\section{Universal design idea and increased accessibility development}

In 1977 architect Michael Bednar noted that the functional ability of all people is usually enhanced when environmental barriers are removed, and suggested the neccessity for a new concept that is 'much broader and more universal' and 'involves the environmental needs of all users' (Bednar 1977). The term 'accessible design' was used in the early 1980s to describe the value of universal design - design for all people. 'Design is a basis for all human activity. The planning and creation of any activity in compliance with the envisaged aim form the sense of such design. Any attempt to separate design, make it a thing goes against the meaning of original base life matrix,' points out Viktors Papaneks (1984). Viktors Papaneks, architect and follower of Frank Lloyd Wright and Buckminster Fuller, stood out with extensive mental outlook and in addition to architecture and design was interested in anthropology, social psychology, ethology and other sciences. Papaneks saw design as a multidisciplinary profession, based on the personal experience. The US Architect Ronald Mace in his turn in 1988 characterized a universal design as a product and design of environment, usable by the number of people as large as possible without necessity to adjust it or improve it for the needs or amenities of separate humans (Mace et al. 1991). American psychologist Herbert Alexander Simon (1916-2001) points out that any design, inventing aspect seeks to change the current situation for the better one. Therefore, design may be formulated as 'transformation of the current situation for better'. Simons was a professor in Karnegie Mellon University, the USA, and his studies covered the spheres of cognitive psychology, computer science, community administration, economics, management, science psychology and sociology (Simon 1969).

He was one of the most influential social scientists in the 20th century with more than a thousand quoted publications. The Norwegian government's action plan for universal design and increased accessibility 2009-2013 interprets the universal design as strategy, not as the minimal standard or universal solution that may be used in all situations, instead - to strengthen citizenship and improve the active participation of people in society. To achieve the aims of the strategy, the following institutions agreed to cooperate: the Ministry of Children, Equality and Social Inclusion, the Ministry of Transport and Communications, the Ministry 
of Environment, the Ministry of Local Government and Regional Development and the Ministry of Government Administration, Reform and Church Affairs. The Nordic Council of Ministers, represented by the Nordic Center for Welfare and Social Issues, and the Council of Europe have confirmed that they will contribute as partners (The Norwegian government's ... 2009). The strategy of universal design will promote the economic and social sustainability that actually will give an amazing contribution to the strategy of the whole country's social sustainability.

Rehabilitation gardens in the 21 st century incorporate the needs of different patients worldwide by providing a space for various activities to improve health in the landscape. Lambe has also highlighted in his work: 'The only difference in a sensory garden is that all these components (hard landscaping, soft landscaping, colors, textures and wildlife) must be carefully chosen and designed to appeal to the senses in such a way that they provide maximum sensory stimulation' (Lambe 1995). In recent years, rehabilitation gardens have been planned specifically and adapted to the needs of different patients. They become valuable means in creation of medical institutions' landscapes where patients have the opportunity to rehabilitate and gain positive emotions. In therapeutic context, a garden usually relates to a small garden that is developed specifically in order to give an opportunity to participate in gardening outdoors between plants actively or passively by observing them (Gaskell 1994). There is a common view that sensory gardens are located near hospitals and meant for people with various health disorders, but for rehabilitation they are being located near special schools or elderly people's homes (The Therapeutic Landscapes... 2014).

Further international practices and design principles of rehabilitation gardens are described, taking into consideration the individual medical needs of patients:

1. Rehabilitation gardens for people with eyesight disorders.

In gardens for people with weak eyesight or blind people informative materials in Braille certainly should be envisaged, indicating not only the directions where to go, but also explaining different things and places in the garden. Blind people, the visual reception and sight of whom have been lost, have more intense other senses, as, for instance, smell and taste that may be promoted in the garden by choosing herbs, berry bushes, fruit trees, tea plants and different aromatic plants (Stoneham, Thoday 1994). Also touch is a sense, helping to perceive the structures and textures in the rehabilitation garden. The territory should be safe, with appropriate barriers and delimitations, so that the movement abilities of patients are not endangered. For persons with eyesight disorders, an opportunity to receive the necessary information from sound should be provided. To make the orientation for patients with weak eyesight easier, landmarks, sound dominants - fountains, bells are usually located in the garden.

2. Rehabilitation gardens for people with hearing disorders.

The landscape and planning of the garden include visual information, easily readable in the landscape itself and with the visual designations. Sculptures and other pieces of art, improving imagination, should be placed in the garden.

3. Rehabilitation gardens for people with movement disorders.

Infrastructure of high quality and principles of the universal design are the most important. Ergonomic and safe garden design ensures a challenging experience through feelings and information not only for people in wheel-chairs but also for the rest of the visitors of the garden. The function that results from the structure of paths, relief - slopes, ramps, returning fields, availability of objects in the garden, and visibility - view lines in the distance and legibility of objects' information on wheel-chair level. Raised planting beds and accessibility to water in wheel-chair should be envisaged in the garden.

4. Rehabilitation gardens for patients with stress-related illness.

Greenery, flowers and water dominate in the environment of such rehabilitation gardens designed for patients' recovery from stress. Long-term studies of professor Ulrich on regeneration of gardens or recovering from stress prove that natural, harmonic landscapes cure and calm down much more that urban landscapes with buildings, cities that the lack of nature elements. Studies witness that looking at a landscape with plants may promote a definite regeneration already after some minutes even to hospital patients with accute illnesses.

In rehabilitation gardens meant for curing people from stress-related illnesses, predominance of hardscape should be avoided. Big, incomprehensible sculptures may cause lack of understanding, desperation that may serve as additional base for stress (Ulrich 1999; Cooper, Marcus 1999). It is important to create several premises in the garden for peaceful sitting alone in the pergola, active walks and activities with other patients. 
5. Rehabilitation gardens for people suffering from cancer.

These patients usually are worried and sad, and this only increases the intensity of their illness. Similarly to the rehabilitation gardens designed for people with stress-related illnesses, natural green landscapes with trees, flowers and water should be used (Ulrich 1999; Cooper, Marcus 1999). The presence of animals and birds in the rehabilitation gardens should be promoted with bird-tables, watering-places and choice of nectar plants; the bees and butterflies create positive emotions in patients. Ambiguous sculptures that patients may interpret as threatening, deterrent and evil, creating pressure and fear, should be avoided.

6. Rehabilitation gardens for people, suffering from dementia and Alzheimer's disease.

They are most often located near elderly nursing homes. For people who suffer from symptoms of dementia, gardens should be developed of closed type - with delimitations and fences to keep people safe and prevent them from any opportunity to get lost outside the territory of the garden. These patients have an explicit loss of memory that may cause agitation and fear. It is also important to avoid dead ends in the garden that may cause agitation for the patient. Pathways in the garden should be developed in a shape of a loop, and entrance in the building has to be well-seen. Much attention should be paid to promotion of good memories, manifested by old memories, childhood experiences, cultural memories through reminders in the garden. It may be achieved through plantation of fruit and berries reminding of pleasant childhood time to promote recovering from dementia in such a way (Copak 1992), as well as porches, hand pumps and clotheslines elements (Zeisel, Tyson 1999).

7. Rehabilitation gardens for functional and mental development of children.

Accessibility of multi-sense (sight, hearing, taste, touch, smell, and imagination) experience, opportunities of education and relaxation in the fresh air are important. The use of a mirror may promote self-confidence in people with learning disorders. For children drums, counting frames and percussion instruments should be placed in the garden. Different textures are used in paths, plants and other elements of the garden. Every child could want and appreciate moments of happiness. Through mist and mud in the garden, children can recovery happiness. Studies of professor Grahn show that by spending more time in nature, there are fewer sick-days, fewer attention and concentration problems, improved motor function (Grahn et al. 1997).

8. Rehabilitation gardens for people with addictions.

Basic principles of garden design should cover not only esthetically enjoyable natural landscapes but also tangible things and things to be felt by soul. People with different kinds of addictions are given an opportunity to regain their reason to live and willingness to live through work and prayers to God in the gardens. By working together in the rehabilitation garden and on building its architecture people have an opportunity to set their minds easier, communicate with each other and participate in creation of their own lives. The psychiatrist and signatory of the United States Declaration of Independence Dr. Benjamin Rush in one of his first descriptions of American medicine declares that 'digging in the garden' and 'chopping wood' may be helpful to 'sufferers of mania' (Rush 1812). With a strict agenda, people take care of the garden, dwelling premises, animals and the surrounding people. Communication through religion and work cure people suffering from addictions. Brukna Manor in Bauska District, Davinu Parish, Latvia, serves an example (Balode 2013d).

\section{Materials and methods}

The functional quality of Latvian rehabilitation gardens and parks has been studied and analyzed. Several methods have been used in the study. Firstly, the analysis of historic materials has been carried out. When analyzing the functional quality of rehabilitation garden, worldwide studies on results of interaction between human being and environment were taken into consideration; on the basis of them the concept of universal garden and park design historically developed. In the framework of the study, also the current Latvian laws on social equality in relation to environmental accessibility, as well as data from the Central Statistical Bureau of Latvia for 2012 on receivers of the old-age pensions and disablement pensions were analyzed.

By using the field study method, 8 Latvian rehabilitation gardens and parks were examined. For the study purposes the largest and most widely visited Latvian rehabilitation centres were chosen. Three of them are located in Jurmala - the national rehabilitation centre Vaivari (Figs 2, 7, 5), rehabilitation centre Jaunkemeri (Fig. 3) and health resort Belorusija.

Two rehabilitation centers in Vidzeme Region were examined: the rehabilitation centre Ligatne located in a beautiful place in the territory of Gauja National Park, and the rehabilitation center Krimulda set up in Krimulda 


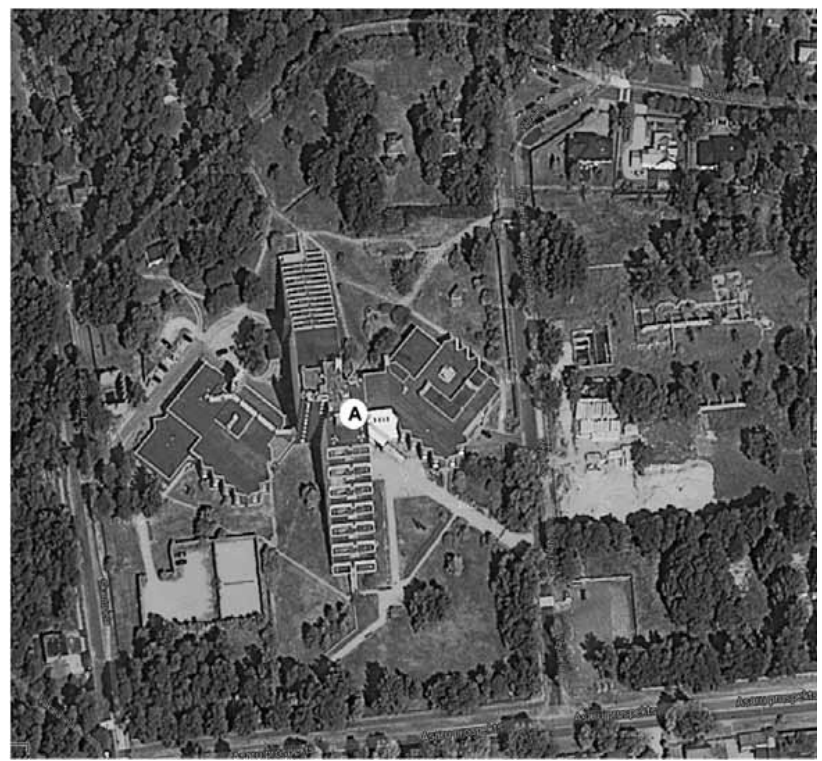

Fig. 2. Latvian rehabilitation centre Vaivari. The Situation aerophoto, Jurmala. Source: compiled by Balode (according to literature review based on (Google... 2014))

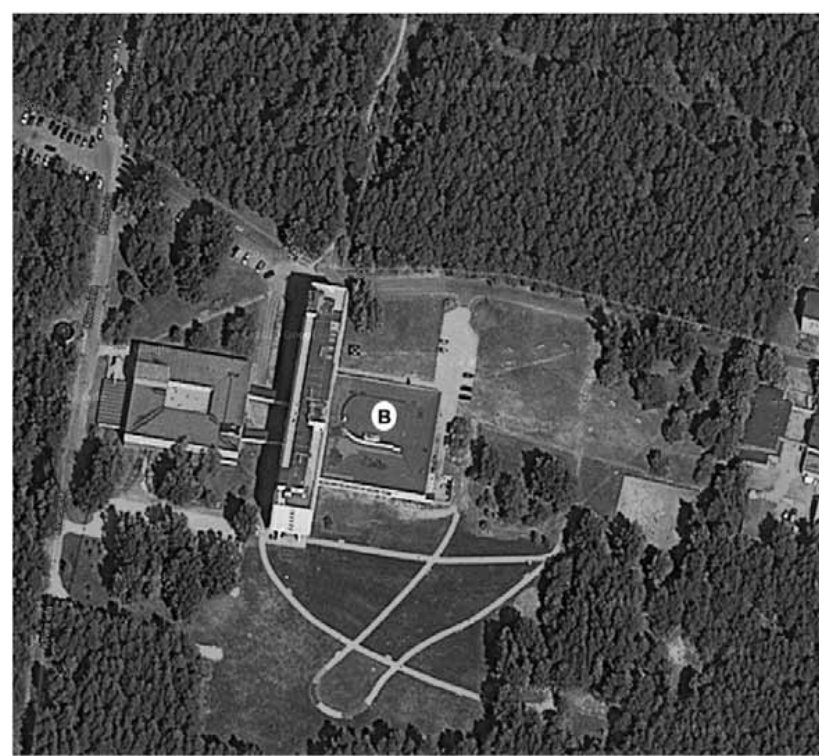

Fig. 3. Latvian rehabilitation centre Jaunkemeri. The Situation aerophoto, Jurmala. Source: compiled by Balode (according to literature review based on (Google... 2014))

Manor house, on the right bank of the picturesque River Gauja. In Zemgale Region three rehabilitation centers were examined. The rehabilitation center Tervete was examined that is located not far from the Lithuanian border in the national architectural monument - the main building of Tervete Sanatorium built in 1932 for 250 patients. The second rehabilitation center examined in Zemgale Region is located in the Bauska District, on the banks of the River Iecava, the Brukna Manor House, built in the 18th-19th century. In all objects the photo fixations and inventory takings were performed, by noting the visible functional ele- ments and their quality (Fig. 6). The Mental Rehabilitation Centre Dujas established in Jekabpils District, Kalna Parish, in the previous Birzu Manor House, was inspected. Due to donations it was reconstructed and opened in summer of 2010 to provide children with special needs, their parents and relatives with psychological support. The territory of the rehabilitation centre Dujas is located in a picturesque place surrounded by natural water landscape (Figs 10, 11).

By using the field study method, 7 Latvian rehabilitation gardens and parks were examined. The largest and most widely visited Latvian rehabilitation centers were chosen for the study. Three of them are located in Jurmala - the national rehabilitation center Vaivari, rehabilitation center Jaunkemeri and health resort Belorusija. In Vidzeme Region two rehabilitation centers were examined: the rehabilitation center Ligatne, located in a beautiful place in the territory of Gauja National Park, and the rehabilitation center Krimulda set up in Krimulda Manor house, on the right bank of the picturesque River Gauja. In Zemgale Region also two rehabilitation centers were examined. The rehabilitation center Tervete was examined that is located not far from the Lithuanian border, in the national architectural monument the main building of Tervete Sanatorium built in 1932 for 250 patients. The second rehabilitation center, examined in Zemgale Region, is located in the Bauska District, on the banks of the River Iecava, the Brukna Manor House built in 18th-19th century. In all objects photo fixation and inventory takings were performed by noting the visible functional elements and their quality.

By using the sociological method, a questionnaire, consisting of 10 questions on the functional quality of Latvian rehabilitation gardens and parks was used. The questionnaire consisted of three parts: the introduction, main part and demographic part. In the questionnaire, the open, closed and semi-closed questions were used. The open questions presented no previously prepared answers (Kristapsone 2008; Babbie 2006). They let the respondents answer with their own words that through the sociological method enrich the study with deep understanding of a person, knowledge and suggestions. Regarding the question on 'elements that are necessary to any of landscapes of Latvian rehabilitation institutions' and on 'elements that would make the respondent feel in harmony and let him/her relax in the rehabilitation garden or park' the ranging method was used.

With the ranging method elements were arranged in diminishing way by placing the most highly evaluated element as the first one in this way finding out the most important and the less important rehabilitation outdoor elements. To measure the society's attitude to and view on the current situation regarding Latvian rehabilitation institu- 
tions' landscapes, Likert scale has been applied (Nachmias 2005; Alreck, Settle 2003). It consisted of 9 subquestions and 5 interval responses.

In the subquestions, opinion on esthetics of building design, quality of stairs and paths, territory fencing, suitability of greenery, relaxation fields for all age groups, lighting, art objects and modernity and convenience of landscapes in Latvian rehabilitation centers was clarified. The five interval responses consist of: "yes", "certainly yes", "no", "certainly no", and includes also a response "do not have an opinion". By using the Likert scale, responses by various individuals have been compared and it has been found out to what extent respondents agree to or disagree with the question (Alreck, Settle 2003).

In total, 116 users of Latvian rehabilitation centers' landscapes were interviewed. Those include Latvian rehabilitation centers' patients, their relatives and service staff who may characterize most truly the current situation in Latvian rehabilitation gardens and parks. During the 8th Baltic Rehabilitation Association Congress on 18-19 September, 2013 in Riga, Latvia, interviews with specialists and experts in the field of rehabilitation were carried out. During the examination of Latvian rehabilitation centers photo fixations and inventory takings were used, as well as summarized the filled in questionnaires on functional quality of rehabilitation gardens and parks. The gained data was codified and processed by using the data processing program Excel and SPSS. Data was analyzed and summarized in the form of tables and graphics.

\section{Results and discussion}

The universal design is used worldwide in different social project developments and improvements and is also defined as the Design for all, Life Span, Barrierfree Design and Inclusive Design.

In the course of time, several countries have acquired the idea of universal design, and the UN Convention On Rights of Persons with Disabilities, Clause 2 states that 'Universal design' means the design of products, environments, programmes and services to be usable by all people, to the greatest extent possible, without the need for adaptation or specialized design. 'Universal design' shall not exclude assisting devices for particular groups of persons with disabilities, where this is needed.

In Latvia, this Convention came into effect on 31 March 2010 (Apvienoto Nāciju... 2013). The aim of the Convention is to promote, secure and ensure that a person with disability could exercise all human rights and freedoms equally to other persons. In its 50 clauses the Convention envisages the observation of equality, prevent- ing of discrimination, protection of women and children with disabilities, ensuring accessibility, creating of understanding, accessibility to court, freedom and immunity of a person.

Upon the adoption of the Convention, the 21 st century gives a new understanding to the Latvian society regarding people with functional disabilities. The Convention transforms the human life model from the one, which was based on the incapability of the disabled and their dependence on other people, to the model of free, independent, human rights-respecting model of living capable and qualified to independent life and active participation in social processes, just like everybody else. Upon change of society's attitude, people with disabilities have an opportunity to receive good education, work, relaxation and enjoy life.

In addition to this legal framework, landscapes and environment of Latvian rehabilitation and other centers have to develop in compliance with the principles envisaged by the Convention. A conceptual direction in design like this is relatively new in Latvia, but already positively accepted and adapted among specialists. The main criteria for environmental accessibility in Latvia are regulated by the Construction Law and the construction norms envisaged in it. In compliance with the Construction Law:

- Chapter 1, paragraph 27: 'accessibility of the environment - a possibility for people with movement, visual or hearing impairments to move in the environment in conformity with the planned function of the structure';

- Chapter 3, paragraph 3: 'a structure shall be designed and constructed so as to ensure the architectonic quality of the environment, accessibility of the environment';

- Chapter 16, paragraph 3.2: 'derogations from the technical requirements of the regulation shall be possible if in carrying out a reconstruction or renovation it is not technically possible to observe the relevant requirements, or the building could lose its cultural and historical value due to the observance thereof.' (Būvniecības... 2013).

Particular requirements and criteria that have to be observed in order to ensure the environmental accessibility have been summarized in the Latvian construction norms. It is possible to get acquainted with the general criteria recommendable for ensuring of the environmental accessibility on the website (Universāls... 2012). These guidelines are recommended to be observed and applied, when designing rehabilitation garden and park landscapes. It is important for environment of such rehabilitation institutions to be friendly, because it is created for the use of 
all social groups and individuals by applying the universal standard principles. Such thinking brings forward a human being as the main value, to whom the environment is being adjusted, taking into account convenience, safety and landscape environment as natural as possible.

According to the data from the Central Statistical Bureau of Latvia, currently there are $10 \%$ of citizens with visual, hearing, movement or mental disorders. According to data from the data base on receivers of pensions and state social security benefits by the end of 2012, approximately 482,000 people were receivers of old-age pensions, who irreversibly faced physiological functional changes limitting their vision, hearing or moving. As well as approximately 70,000 people received disablement pensions (Sociālā drošība... 2013).

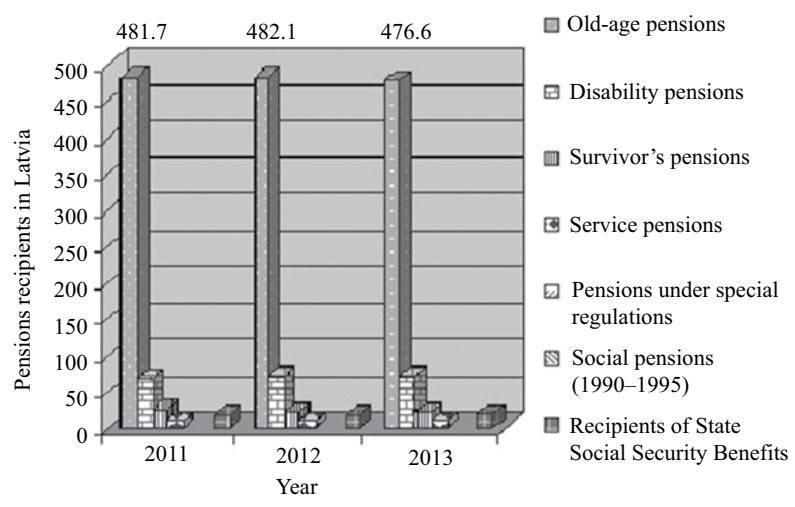

Fig. 4. Recipients of pensions and state social security benefits in Latvia, the 2011, 2012 and 2013 year.

Source: compiled by L. Balode, data from the Central Statistical Bureau of Latvia, 2014

The majority of these people visit rehabilitation centers, where gardens and parks are places where they should feel comfortable in outdoor environment and receive valuable attitude from the surrounding people. It also should not be forgotten than none of us is protected from physical injuries that may cause movement disorders. Most often a person after injuries has to use special aids: crutches, wheelchair or help of an assistant. In such cases a person needs a safe and even surface in nature, as well as enough space to turn in the wheelchair. Such accessible environment has to be ensured not only for people with movement disorders, injuries and old people, but also for mothers using prams. Chapter 8 the Fundamental Human Rights of the Constitution of the Republic of Latvia says that all citizens have equal rights:

- Paragraph 89: 'The State shall recognise and protect fundamental human rights in accordance with this Constitution, laws and international agreements binding upon Latvia.'

- Paragraph 91: 'All human beings in Latvia shall be equal before the law and the courts. Human rights shall be realised without discrimination of any kind.'

- Paragraph 94: 'Everyone has the right to personal liberty and security. No one can be deprived of or have their liberty restricted, otherwise than in accordance with the law.' (Cilvēka pamattiesības... 2013).

By carrying out the inspections of rehabilitation centers in nature, I got acquainted with the current situation in the landscape accessibility and usability. The quality of rehabilitation centre paths and economical aspect make it impossible to stay freely in nature for every man, also using a wheelchair, and for the patients to socialize with each other. It was concluded that the major part of the landscapes of these centers are old-fashioned and essentially limit freedom of movement and relaxation for majority of people. Pedestrial paths paved in the Soviet times are worn out (Fig. 5), majority of benches are broken, design of laterns not aesthetical and big trees in the greenery - outgrown.

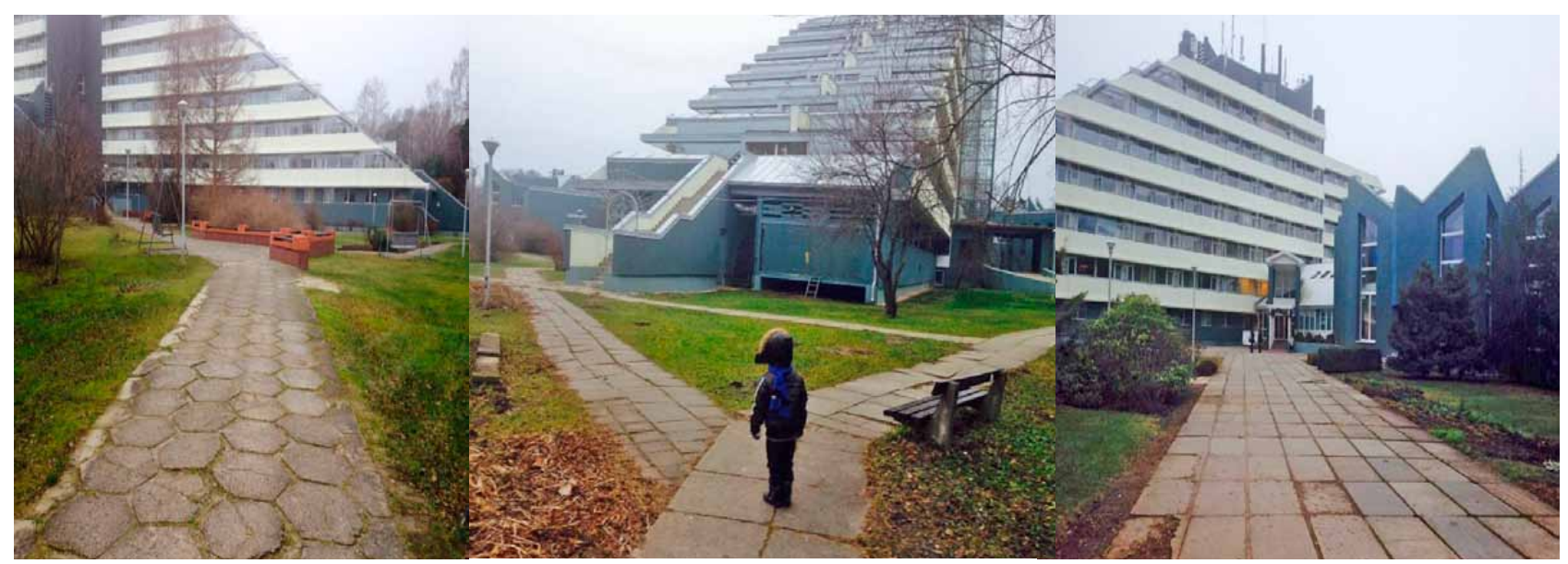

Fig. 5. The wheelchairs' quality and economic aspect in the Vaivari rehabilitation garden.

Source: L. Balode's private archive, 2014 

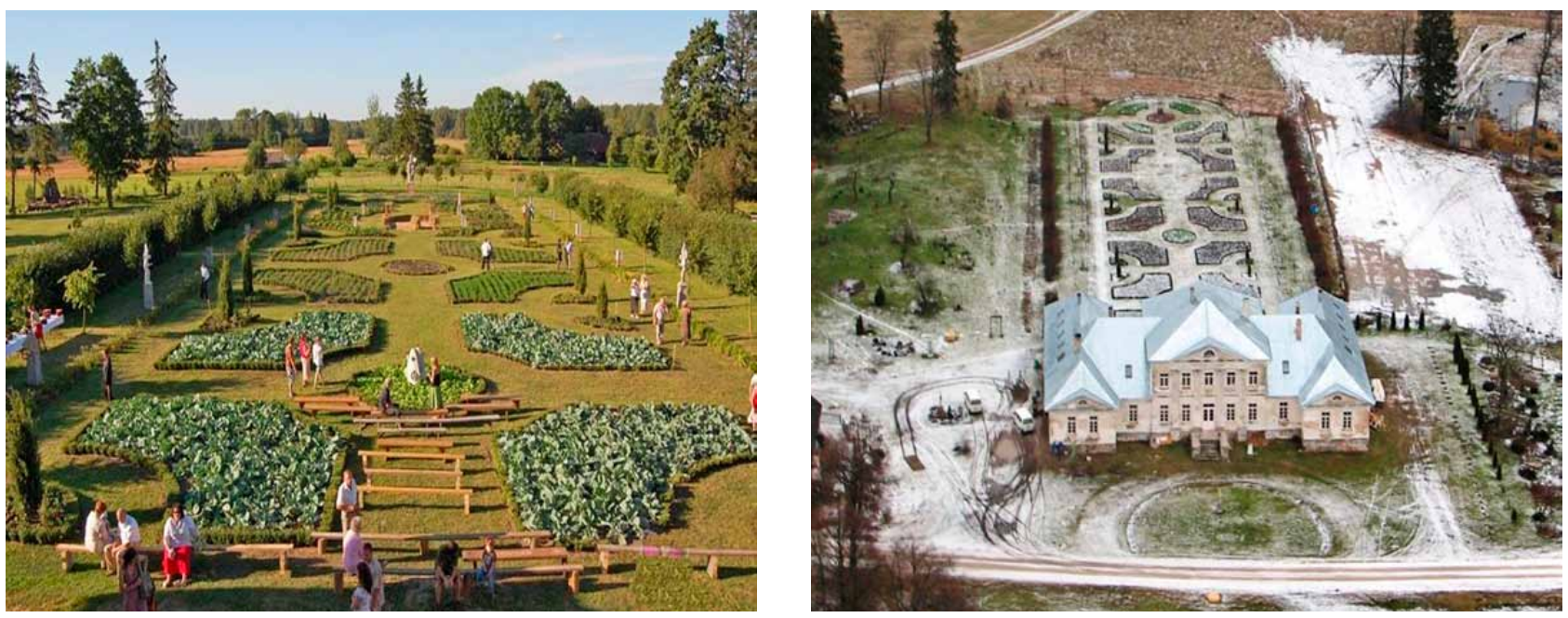

Fig. 6. The renaissance style vegetable garden in the rehabilitation centre Brukna Manor, Bauska.

Source: L. Balode's private archive, 2013

Due to the economic reasons, the rehabilitation centers are being renewed and modernized very slowly. Initially the reconstruction is made in the buildings, interior and only then attention is paid to the surrounding landscape.

During the inventory taking, some positive indicators were found in the territory of Brukna Manor House, where the greenery was found being renewed and supplemented every year, as well as planting beds for vegetables in the renaissance style being made (Fig. 6) with the content of vegetables being changed every year. The lighting was found being applied in an interesting way by lighting up the facades of the Brukna Manor House, as well as water elements and sculptures widely used in the territory. In the rehabilitation garden of the Brukna Manor, through prayers for God's blessing and mutual social communication between patients, assistance is provided to people who have lost hope and any the reason of living, have fallen into

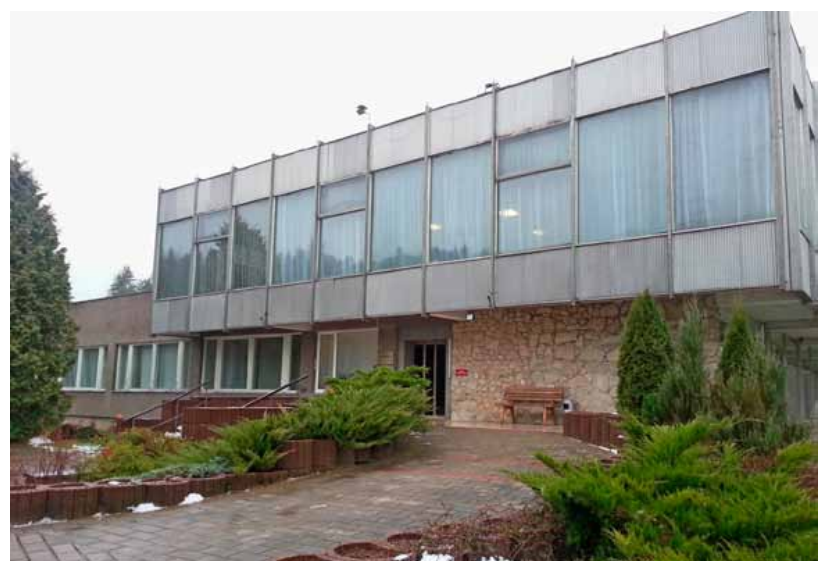

Fig. 7. The comfortable ramps for wheelchairs and prams in the rehabilitation centre Ligatne.

Source: L. Balode's private archive, 2013 drug addiction, alcohol or other addictions. Nature, season change, rhythm of liturgical time, prayers, field works, care of reconstruction and maintaining of the Brukna Manor give an opportunity to people to purify themselves, both physically and mentally, and return to normal life (Ušča 2013; Balode 2013d, b). Jesus is in the centre of the community's life. Problems in human souls are being cured through prayers. The period for rehabilitation and social adaptation is individual - from 1 to 3 years.

In all of the main entrance zones of all Latvian rehabilitation centers inspected, wintergreen flower-beds dominate. The main entrances of rehabilitation centers are the most aesthetic, visually attractive and functionally developed. The main entrances of Latvian rehabilitation centers have comfortable ramps for wheelchairs and prams (Figs 7, 8), equipped with handrails and comfortable width of doors, not less than $90 \mathrm{~cm}$.

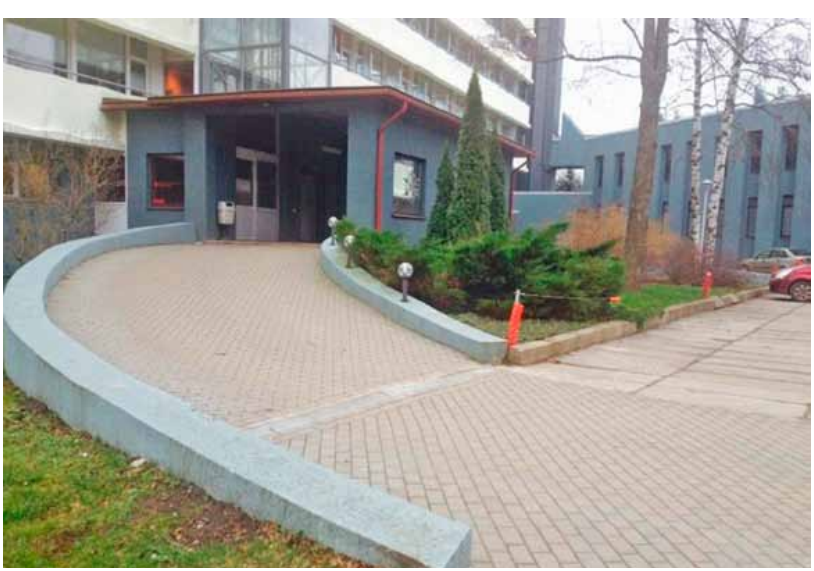

Fig. 8. The comfortable ramps for wheelchairs and prams in the rehabilitation centre Vaivari.

Source: L. Balode's private archive, 2014 
The buildings of rehabilitation centers usually are of big size and painted in light colors. They often prevail over the rest of the rehabilitation landscape. In the questionnaires, the majority of respondents replied that the design of buildings of Latvian rehabilitation centers is not interesting. The results of the questionnaire showed that $40.16 \%$ out of 122 respondents highlighted - undecided, but $35.25 \%$ noted that the architecture of the main buildings of Latvian rehabilitation gardens is not enjoyable visually. Due to financial reasons, the buildings have not been renewed, they are old and thus are not enjoyable. $3.28 \%$ out of 122 respondents saw esthetically and architecturally enjoyable buildings in the complexes of Latvian rehabilitation centers, and it is a very low index (Fig. 9). The design of monolith buildings possibly needs brighter decorative and contemporary elements. In the landscapes of the surroundings, wide and open green fields may be seen that highlight the mightiness of the buildings.

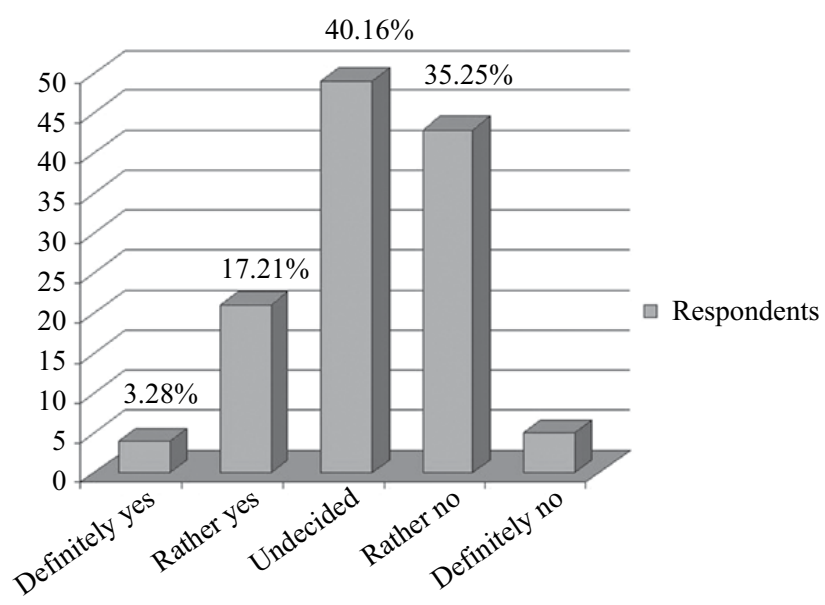

Fig. 9. Visual evaluation of Latvian rehabilitation centre buildings. 122 respondents. Source: Compiled by L. Balode, 2014

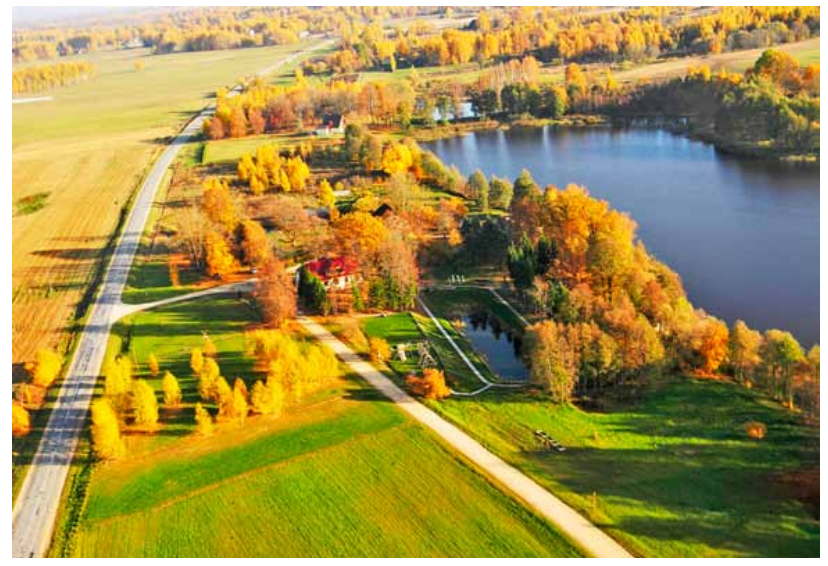

Fig. 10. Rehabilitation centre Dujas aero photo. Source: I. Rancans private archive, 2013
The newly established Latvian rehabilitation centres rehabilitation centre in the Brukna Manor, Davinu Parish, and rehabilitation centre Dujas in Kalna Parish - are incorporated organically in the natural landscape. Green fields and hills covered with plants and blue spots of water create harmonious places for rehabilitation and continuous communication between patients and nature. There are several landscapes developed in the rehabilitation centre Dujas (Fig. 10) with a playground, water landscape, decorative plantation, beds of herbs and relaxation zone with distant views on landscapic meadows (Fig. 11). The territory contains pedestrian paths. Preservation of big trees in the landscape, where the sunbeams, wind and shadows can play, is an important feature.

The big trees make a perfect habitat for birds, squirrels and insects. An important moment is the exposition of distant views, so that it would be possible to enjoy the distant landscapic perspectives of fields. There is also the opportunity of mutual communication between nature and people assisting in the rehabilitation process.

Natural environment is being considered especially effective as the main factor of a person's successfully rehabilitation, restoration of physical strength and mental energy. Nature ensures a space where human beings may obtain peace with themselves and environment (Balode 2013a).

The rehabilitation centres also incorporate the use of the surrounding natural resources - the Baltic Sea, the River Iecava, the River Gauja, the Tervete Nature Park and Gauja Nature Park - for active sports in the recovery process. During the inspection it was found out that the rehabilitation centres mostly lack separate, confined relax zones, pergolas near buildings, where patients could have opportunities to spend time of their own without any disturbance or together with their relatives.

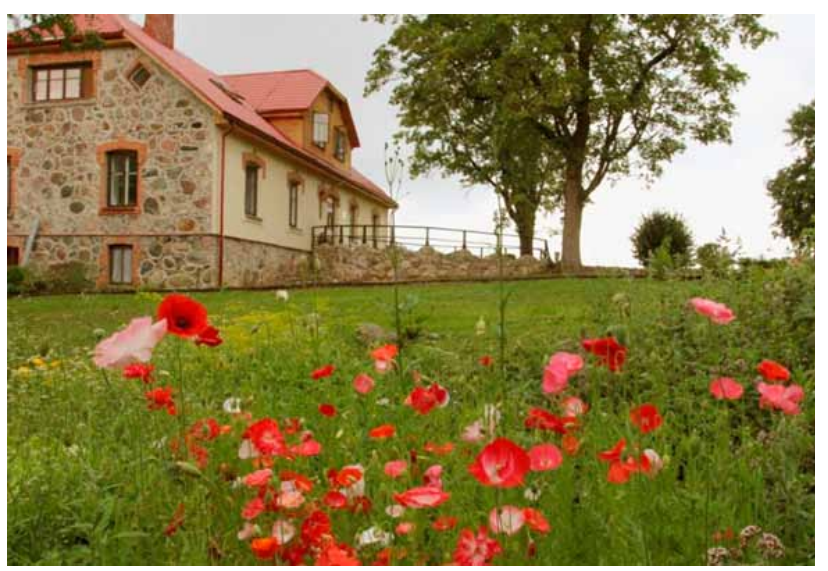

Fig. 11. The landscape of a meadow in bloom at the rehabilitation centre Dujas.

Source: L. Balode's private archive, 2013 
The Health Resort Belorusija is located in the sanddune area. It is surrounded by the park of pine trees with the sea shore being at 100 metre distance. Vicinities of the rehabitation centre may be used for exercising v.s nordic walking. Currently so popular way of active recreation appeared at the beginning of the 1930s thanks to professional Finnish skiers who wanted to maintain their physical form in all seasons (Nüjošanas.... 2012). As specialists point out at regular walk (without poles) load is ensured only for the lower part of human body, but during Nordic walking also to the upper part. By operating actively with arms, an individual strengthens arm muscles, as well as abdominal muscles. A professional instructor helps to prepare for walks, teaches how to move correctly, as well as gives valuable advice. Except Nordic walking, there is a possibility to play volleyball on the beach. This exciting and venturous game has many supporters and spectators. Beach volleyball is most popular in Jurmala; on its beaches dozens of professional and amateur competitions take place every year. Physical activities in fresh air are supplemented by badminton and frisbee played on the grass. The rehabilitation center Jaunkemeri also has a possibility to do the Nordic walking and spend time by the sea. Tennis courts are established not far from the sea, in the rehabilitation center Vaivari. In Brukna Manor House, a football field is set up with a place for swimming and place for fishing arranged at the bank of the River Iecava. There is an opportunity to enjoy an active relaxation in rehabilitation centers of Ligatne and Tervete in the nearby nature parks. A visit to thematic walking paths, the Nordic walking and cycling route are offered there. The location of the rehabilitation center Tervete in the nature park promotes mental and emotional recovery of patients, as well as gives an opportunity of useful spending of free time by walking in Dwarfs' Forest, climbing to Tervete Castle Mound in Ragana Pine Forest, as well as visiting the museum of A. Brigadere Spridisi. In the rehabilitation center of Krimulda, a thematic excursion can be arranged, during which an opportunity is provided to get acquainted with the samples and get useful information about the use of wild plants and cultivated plants favorable to our health. Everyone has the opportunity to taste the healing water from the Princess fontanel and different herbal teas.

The results of the questionnaire show that the territories of the rehabilitation centers lack separate fields for relaxation and outdoor activities. These opportunities have been switched to nature parks, shores of sea and river, accessible in the surroundings. In the territories of the rehabilitation centers more attention should be paid to creation of small relaxation and sitting places that might be used by everyone, independent from a person's age and health.
Insolation, shading and prevailing winds definitely should be taken into account, when planning such places.

Also the quality of benches in many places is unacceptable. A significant part of the respondents revealed that they would like to have chairs for sunbathing in the rehabilitation gardens and parks; they assessed the architecture of gardens and parks as outdated. People wish modern and contemporary lighting elements, outdoor fitness equipment, open-air cinema and sensor feeling gardens, where an opportunity could be provided to enjoy nature with all five senses.

The majority of pieces of art in these gardens are of dynamic character. Swings, little bridges, sundials, wind dials, belveders for bird-watching and raised planting beds for people with movement disorders are set up in the gardens. Attention has to be paid to attraction of birds, fish and other animals. Interesting sounds come also from wind, wooden or clay bells. For the children the drums, counting frames and percussion instruments are arranged in the gardens. Bird cages, bird tables and decorative watering places are also placed in the territory. In choosing plants attention is paid to nectar plants in order to attract bees, butterflies and other insects. For people with eightsight disorders and blind plants with interesting smell, taste and structure of leaves are envisaged. Garden is being supplemented with descriptions of plants and places in Braille. The feeling garden is a continuous dialogue between a human and nature that invites to participate and study (Balode 2013c). The functional quality of relaxation places is characterized not only by the quality of benches and lighting, but also by walking paths of high quality with comfortable stairs and ramps. According to the respondents, the most important element also characterizing the quality of the rehabilitation centers were walking paths of high quality (Fig. 12).

Often more attention in the rehabilitation centers is paid to the indoor design forgetting about the outdoor quality discriminating in such a way the opportunity of any person to spend time comfortably in the rehabilitation center's garden or park.

In the 8th Baltic Rehabilitation Association Congress held from 18-19 September 2013 in Riga, Latvia, very interesting and substantial facts were revealed during an interview with specialists and experts in the rehabilitation field. Ergotherapy specialist, deputy director of the LU Botanical garden, Dr. Med. Signe Tomsone: 'The attention has to be paid to commercial view how to put in order and maintain rehabilitation landscape, so that it functions. Is there a possibility to involve a professional gardener?' Also psychologist, drama therapist Agnese Rozlapa-Grase 


\begin{tabular}{|c|c|c|c|c|c|c|c|}
\hline & 1. place & 2. place & 3. place & 4. place & 5. place & 6. place & 7. place \\
\hline Interesting building design & $10.66 \%$ & $9.02 \%$ & $7 . \dot{38} \%$ & $9.84 \%$ & $10.66 \%$ & $21.31 \%$ & $31.15 \%$ \\
\hline Paths, stairways quality (ramps) & $46.72 \%$ & $15.57 \%$ & $11.48 \%$ & $9.84 \%$ & $8 . \dot{2} \%$ & $4.1 \%$ & $4.1 \%$ \\
\hline Territories limitation, fencing & $7.38 \%$ & $16.39 \%$ & $18.85 \%$ & $9.84 \%$ & $13.93 \%$ & $12.3 \%$ & $21.31 \%$ \\
\hline Harmonically plantings & $14.75 \%$ & $11.48 \%$ & $13.11 \%$ & $15.57 \%$ & $22.95 \%$ & $13.93 \%$ & $8 . \dot{2} \%$ \\
\hline $\begin{array}{l}\text { Individually areas (different age groups } \\
\text { for recreation and outdoor activities) }\end{array}$ & $27.87 \%$ & $14.75 \%$ & $13.11 \%$ & $13.93 \%$ & $12.3 \%$ & $7 . \dot{38 \%}$ & $10.66 \%$ \\
\hline $\begin{array}{l}\text { Lightings and information } \\
\text { in outdoor space }\end{array}$ & $23.77 \%$ & $27.87 \%$ & $18.03 \%$ & $10.66 \%$ & $9.84 \%$ & $5.74 \%$ & $4.1 \%$ \\
\hline Parking areas & $19.67 \%$ & $6.56 \%$ & $19.93 \%$ & $18.03 \%$ & $10.66 \%$ & $16.39 \%$ & $14.75 \%$ \\
\hline
\end{tabular}

Fig. 12. Evaluation of elements in the Latvian rehabilitation gardens and parks by importance. 122 respondents valued landscape elements in the Latvian rehabilitation centres with the 1. place as the most important; with the 7. place as the least important.

Source: compiled by L. Balode, 2014

points out that 'only in rare cases the environment in the Latvian rehabilitation gardens and parks is tidy and appropriate. Additional financing should be found for putting landscapes in order and creation of them - favorably by involving gardeners that are competent in this field.'

Ilze Paparinska is the founder of the medieval (14th-17th century) dance group Kalendula. She offers for 3 to 5 year old children to participate in dance and movement therapy together with their mothers. The aim of the therapy is to decrease symptoms of bronchial asthma, acquire relaxation and breathing techniques in safe and creative environment that may improve their life quality. 'The nice feelings during the dance may be compared just to the celebration of life.' Dance and movement therapist Ilze Paparinska noted the following three main problematic aspects of landscape space to develop:

- Poor quality road surface - hardly usable for a wheelchair user;

- Lack of aesthetic greenery;

- Lack of open-air pergolas - private space.

When asked what harmonious environment of high quality means to patients of rehabilitation institutions, I. Paparinska replied: "positive emotions, movement opportunities, communication opportunities outdoors, private space outside the institution, relaxation and aesthetic delight!".

Ergotherapist Anita Pentjusina has the Master Degree obtained at Riga Stradins University in Society's Health. She admits that "Everyone loves to be in an arranged environment. Human is diverse. In addition to tiring pro- cedures there is an opportunity to relax and calm down. There is peace and confidence, if the environment is accessible.' By characterizing the current situation in the country A. Pentjusina says: "If the rehabilitation institution is private, then the owner pays attention to the arrangement of environment, including that designed for patients with movement disorders. But if it is a national rehabilitation center, it gets as much attention as the remaining financing. Most often it is enough only for benches. For instance, in the Latvian rehabilitation center Jaunkemeri they think about it much more!".

In the future, there is a need for more in-depth study of the Latvian suitable plants, roads and squares structure and other elements to facilitate therapy and use of the garden according to local climatic conditions. To achieve the goal, it is necessary to absorb the international experiences and exchange best practices, innovative solutions and adapt the advanced rehabilitation center area landscape for individual needs (Balode 2013b).

\section{Conclusions}

The landscape design of the rehabilitation center most directly influences the way a person feels and lives in the landscape. It creates not only the material quality of the environment, but also improves opportunities for people to communicate. During the recovery for any person his/her communication with their relatives and surrounding people is substantial. On the basis of examining the aesthetic and functional environment, there is totality of the whole sys- 
tem in which various types of environmental expressions transform in one. Theoretical regularities, mutual relationship of practical environment and human and mutual manifestations of aesthetic culture and arts where aspects of human health are seen as one whole. That relates to a human being's social communication model, emotional balance, mental development and informative accumulation of cognition, acceptance of mental world, physical fitness and development of personality. So in general rehabilitation gardens should provide a multifunctional landscape space that allows for any individual to find the most appropriate for themselves.

It may be quiet, separate space in rehabilitation center's landscape for sitting alone, for reflection and meditation, or another space in landscape for communication with others, the relatives. When planning and creating the territory of rehabilitation gardens and parks, the free choice principle has to be taken into account by letting to choose opportunities for walking, relaxing or outdoor activities, suitable to everyone's needs. It is important for the environment of Latvian rehabilitation institutions to be friendly, because they are created for the use of all social groups and individuals by applying universal standard principles for improvement of open space. At most of the Latvian rehabilitations institutions the green area is obsolescent and non-functional.

During the examination I realized that Latvian rehabilitation gardens and parks are not fully accessible to everyone. Most of the paths, paved in the Soviet times are already worn out and have to be renewed. But the positive aspect was that entrances of rehabilitation centers were equipped with ramps and railing. At present a great number of rehabilitation institutions have quite minimal opportunities for relaxation outdoors. Separate benches are offered, but no private spaces in the landscape are arranged by taking into consideration the wind direction, sun intensity, noise, emotional feelings, landscape views, as well as individual physical interests for peaceful walks or active sport outdoors. Only with applied interdisciplinary method it is possible to create the landscape appropriate to rehabilitation of full value. The interdisciplinary method with cooperating professionals of various fields being involved could ensure the comprehensive functional evaluation of the landscape. In such team of interdisciplinary professionals a social worker, ergotherapist, psychologist, architect and landscape architect have to cooperate, as well as significant attention has to be paid to opinions and views of patients. Observation of notions 'equality' and 'discrimination' in rehabilitation gardens and parks is to be understood as ensuring of sufficient environment information and accessibility of physical environment to all patients and visitors. Patients have to be provided with an opportunity to move freely in wheelchairs, prams, by ensuring visitors of rehabilitation gardens and parks with road surface of good quality, ramps with appropriate inclination, railing, appropriate door size and elevators. Surface has to be of high quality and appropriate in order not to cause opportunity to stubble or slip for people with injured leg, crutches or using wheelchair. Grass, gravel road, road paved with stones, sand, uneven, worn out surfaces of poor quality may cause tiring or even dangerous burden to move for people with walking stick, people in wheelchair or people with prams. People with sensor function disorders in rehabilitation gardens and parks have to be ensured with accessibility to information, taking into consideration the display of information, its content and form by providing information also to people with mental development disorders in an easily understandable way, in symbols, but for blind people providing information in Braille. In Latvia it is possible to consult with a certified environment accessibility specialist that has movement disorders himself. Such a specialist may evaluate the environment most precisely and suggest the most appropriate solution for ensuring accessibility. Information on such specialists may be found in the association of the disabled and their friends 'Apeirons'.

\section{References}

Alreck, P.; Settle, R. 2003. Survey research handbook. 3rd edition. New York: McGraw-Hill/Irwin, 116-120.

Apvienoto Nāciju Organizācijas Konvencijas par personu ar invaliditāti tiesībām īstenošanas pamatnostādnes 2014-2020 gadam. 2013. [United Nations Organization Convention for Persons with Disabilities Rights implementation Guidelines for 2014 to 2020]. Ministru kabinets. Rīga, 85 lpp, [online], [cited 1 January 2014]. Available from Internet: http:// www.lm.gov.lv/upload/2013junijs/lmpamn_040613_inv.pdf (in Latvian).

Babbie, E. 2006. The practice of social research. 11th edition. Wadsworth: Cengage Learning, 243-245.

Balode, L. 2013a. Dziedinošie sajūtu dārzi un parki [The Healing Gardens and parks of Senses], Latgales Tautsaimniecības pētījumi. Sociālo zinātnu žurnāls 1(5): 7-22. Rēzekne: RA Izdevniecība. ISSN 1691-5828 (in Latvian).

Balode, L. 2013c. Sajūtu dārzu plānošanas specifika. 21 gadsimta tendentes [The Sensibity' Gardens planning specifics. 21st century tendentes], LU 71. zinātniskā konference. Referātu tēzes, 4-5 p. [online], [cited 5 February 2014]. Available from Internet: http://www.geo.lu.lv/petnieciba/lukonferences/ lugzzfzinatniskokonferencutezukrajumi/ (in Latvian).

Balode, L. 2013b. The health gardens development plan in Latvia, in $1^{\text {st }}$ National Conference on Family Medicine and Primary Care and National Consultation on Family Medicine Programme, 20-21 April, 2013, New Delhi. India, New Delhi: Academy of Family Physicans of India. 98 p.

Balode, L. 2013d. Environmental engineering and landscape architecture rural engineering and information and communation technologies. The design guidelines of terapeutic sensory garden. Research for Rural Development 2013. Jelgava: $L L U$ scientific Articles 2: 114-119. 
Bednar, M. 1977. Barrier free environments. Stroudsburg, Pa.: Dowden, Hutchinson, and Ross. 278 p.

Būvniecības likums. 2013 [Building Act]. Latvijas republikas tiesību akti [online], [cited 6 November 2013]. Available from Internet: http://m.likumi.lv/doc.php?id=36531 (in Latvian).

Cilvēka pamattiesības. 8.nodaļa. 1998 [Fundamental human rights. Chapter 8]. Latvijas republikas saema [online], [cited 5 November 2013]. Available from Internet: http://www.saeima. lv/Likumdosana/likumdosana satversme.html (in Latvian).

Cooper Marcus, C.; Barnes, M. (Eds.). 1999. Healing gardens: therapeutic benefits and design recommendations. New York: John Wiley, 27-86.

Copak, I. 1992. Im Alexianer-Krankenhaus Münster als Gartenplanerin angestellt. Von der Außenanlage zum Nutzgarten für Menschen mit Demenz, 14-15 (in German).

Gaskell, J. 1994. Sensory Gardens (3), Growth Point Autumn (206): 15-32.

Google Maps. 2014 [online], [cited 5 January 2014]. Available from Internet: https://www.google.lv/maps/

Grahn, P.; Martensson, F.; Lindblad, B.; Nilsson, P.; Ekman, A. 1997. Ute $p$ a dagis [Outdoors at daycare institutions]. Stad and Land. Nr. 145 (in Swedish).

Kristapsone, S. 2008. Zinātniskā pētniecība studiju procesā. Rīga: Turība, 245 p. (in Latvian).

Lambe, L. 1995. Gardening: a multisensory experience, in Hogg, J.; Cavet, J. (Eds.). Making leisure provision for people with profound and multiple learning disabilities. London: Chapman and Hall, 113-130.

Mace, R.; Hardie, G.; Plaice, J. 1991. Accessible environments: toward universal design, in Preiser, E.; Vischer, J.; White, E. T. (Eds.). Design interventions: toward a more humane architecture. New York: Van Nostrand Reinhold. 156 p.

Nachmias, D. F. 2005. Research methods in the social sciences. 5th edition. London: Arnold. $465 \mathrm{p}$.

Nūjošanas vēsture. 2012 [Nordicwalking history]. Nūjotāju mājas lapa [online], [cited 5 January 2014]. Available from Internet: http://www.nujo.lv/vesture.htm (in Latvian).

Papanek, V. 1984. Design for the real world. Completely revised second edition. Academy Chicago Publishers. 3 p.

Polyanskiy, A. T. 1988. Arkhitektura kompleksov otdykha. sh M.: Stroyizdat (in Russian).

Roger, S.; Ulrich, R. S. 2002. Paper for conference, Plants for People. International Exhibition Floriade. 10 p.

Rush, B. 1812. Medical inquiries and observations upon diseases of the mind. 226 p. [online], [cited 26 February 2014]. Available from Internet: http://deila.dickinson.edu/ theirownwords/title/0034.htm

Simon, H. 1969. The sciences of the artificial. Cambridge: MIT Press. $241 \mathrm{p}$.

Sociālā drošìba - Galvenie rādìtāji. 2013 [Social safety - main indicators]. LR Centrālā statistikas [cited 17 December 2013]. Available from Internet: http://www.csb.gov.lv/statistikas-temas/ sociala-drosiba-galvenie-raditaji-30402.html (in Latvian).

Stoneham, J.; Thoday, P. 1994. Landscape design for elderly and disabled people. Chinester: Packard Publishing Ltd. 232 p.
The Norwegian government's action plan for universal design and increased accessibility 2009-2013. 2009. Norwegian ministry of Children and Equality [online], [cited 1 January 2014]. Available from Internet: http://www.regjeringen.no/upload/ BLD/Nedsatt $\% 20$ funksjonsevne/Norway $\% 20$ universally $\% 20$ designed $\% 20$ by $\% 202025$-web.pdf

The Therapeutic Landscapes Network [online], [cited 20 January 2014]. Available from Internet: http://www.healinglandscapes.org/about/history.html

Tkhor, E. A. 1984. Detskiye kurortno-ozdorovitelnyye uchrezhdeniya i kompleksy. sh M.: Stroyizdat (in Russian).

Universāls dizains. 2012 [Universal design]. Apeirons [cited 1 January 2014]. Available from Internet: http://www. videspieejamiba.lv/lat/universalais_dizains (in Latvian).

Ulrich, R. S. 1999. Effects of gardens on health outcomes: Theory and research, in Cooper Marcus, C; Barnes, M. (Eds.). Healing gardens: therapeutic benefits and design recommendations. New York: John Wiley, 27-86.

Ušča, A. 2013. Sakārtota vide - nākotnei un attīstībai. Rubrika: Vide ap mums, Izdevums: Bauskas dzive (in Latvian).

Zeisel, J.; Tyson, M. 1999. Chapter 9, Alzheimer's Treatment Gardens, in Cooper Marcus, C.; Barnes, M. Healing gardens: therapeutic benefits and design recommendations. New York: John Wiley, 437-504.

\section{REABILITACIJOS CENTRU SODU IR PARKU ATVIRŲJŲ ERDVIŲ SOCIALINIS ASPEKTAS}

\section{Balode}

Santrauka

Tiriant Latvijos reabilitacijos centrų sodų ir parkų erdves, pagrindinis demesys buvo skiriamas socialiniam aspektui, gilinantis ne tik $\mathfrak{i}$ estetines savybes, bet ir $\mathfrak{i}$ funkcines kraštovaizdžio vertes. Reabilitacijos centrų sodų ir parkų erdvèse žmonès ne tik mediciniškai gydomi, bet ir turi galimybę atsipalaiduoti gamtoje, užsiimti fizine veikla ir ilsètis nepaisant asmens socialinio statuso, amžiaus, lyties, tautybės, politinių pažiūrų ar religijos. Straipsnio tikslas - apibendrinti, kaip Latvijos reabilitacijos centrų sodai ir parkai skatina pacientų fizinę veiklą atvirame ore analizuojant reabilitacijos centrų sodų ir parkų kraštovaizdžio funkcinę kokybę. Kalbant apie reabilitacijos centrų aplinkos kokybę, būtina pabrèžti jų prieinamumą ir naudojimą galimam platesniam veiklos spektrui, ịvardijamam projekto universalumu. Latvijoje ši konceptuali projektavimo kryptis yra reliatyviai nauja, bet jau pripažinta ir palankiai vertinama specialistų. Reabilitacijos centrų sodų ir parkų erdvès daro tiesioginę ịtaką žmogus savijautai kraštovaizdyje. Jos formuoja ne tik materialią aplinkos kokybę, bet kartu lengvina žmonių gebejimą bendrauti ir tarpusavio nusistatymą. Svarbu, kad Latvijos reabilitacijos centru institucijos kurtų palankias sąlygas naudoti jų sodų ir parkų erdves bet kuriai socialinei grupei ar asmeniui pagal universalius standartinius atvirujų erdvių tobulinimo principus.

Reikšminiai žodžiai: reabilitacijos centrų sodai ir parkai, universalus projektavimas, kraštovaizdžio panauda, prieinamumas, socialinis aspektas. 